\title{
Assessing pesticide wet deposition risk within a small agricultural watershed in the Southeastern Coastal Plain (USA)
}

\author{
Thomas L. Potter*, ${ }^{*}$, Alisa W. Coffin ${ }^{\text {a }}$ \\ *Corresponding author phone: 229-386-7073; email: Tom.Potter@ars.usda.gov \\ ${ }^{a}$ T.L. Potter and A.W. Coffin, USDA Agricultural Research Service, Southeast Watershed \\ Laboratory, Tifton, GA 31793 USA.
}

Mention of trade names or commercial products in this article is solely for the purpose of providing specific information and does not imply recommendation or endorsement by the U.S. Department of Agriculture.

Key words: rainfall, endosulfan, chlorothalonil, metolachlor, ecological risk assessment, 


\section{ABSTRACT}

Pesticide volatilization and deposition with precipitation is widely documented and has been connected to adverse ecological impact. Here we describe a 3-yr study of current use and legacy pesticides in event-based rain samples within a 123-ha agricultural watershed. Crops in farm fields were documented quarterly with data used to estimate target compound use. The median number of pesticide detections in samples was 6. The fungicide, chlorothalonil which was used most intensively was detected in nearly all samples. It had the highest mean and peak concentrations with total deposition $\approx 0.1 \%$ of the estimated amount applied. The insecticide endosulfan also had relatively high use with behavior mirroring chlorothalonil. There was strong seasonal variation in concentration and depositional dynamics with the highest values measured during growing seasons. Similar behavior was observed with other compounds detected in rain samples with a general decrease in deposition and mean concentrations as use decreased. Comparison of measured concentrations to values associated with toxic impact on aquatic organisms indicated that chlorothalonil, endosulfan, chlorpyrifos, malathion and atrazine may contribute to adverse impact. The number of samples exceeding risk endpoints ranged from 1 to $77 \%$. The highest value was for endosulfan; however its on-going phase-out is expected to reduce risks. Another finding was that the wet deposition of the herbicide, metolachlor exceeded measured runoff rates in the watershed by 5-fold. The study has demonstrated that localized pesticide wet deposition may present ecological risks and that volatilization and wet deposition is an important pesticide transport pathway at the local scale. Findings point to the need to include wet deposition in assessments of pesticide ecological risk and environmental fate. 


\section{INTRODUCTION}

Evaporation from soil, plant, and other treated surfaces results in pesticide transfer in the gas phase into the atmosphere. As a process this is commonly termed volatilization and can occur during or post-application. The topic has been investigated for more than 50 years and periodically reviewed (Abbott et al., 1965; Bedos et al., 2002; Mejewski and Capel, 1995; Spencer et al., 1973; Van den Berg et al., 1999). Studies have indicated that post application volatilization losses span a broad range, from $0.2 \%$ to more than $90 \%$ of applied (Barbash, 2007; Van Pul et al., 1998). The magnitude of losses was linked to pesticide physical chemical properties including: vapor pressure; Henry's law constants; potential to sorb to soil, plant, and other treated surfaces; and diffusion coefficients. Volatilization losses were also linked to climatic conditions, soil water status, mode of application including spray characteristics and formulation, plant uptake, and management practices, such as soil incorporation and conservation tillage (Alleto et al, 2009; Barbash, 2007; Bedos et al., 2002; Bedos et al., 2010; Woodrow et al., 1997).

Once in the atmosphere, gas phase pesticides are subject to advective and diffusive transport, photochemical oxidation and degradation, sorption on aerosols and particulate matter, and wet and dry deposition. Transport distances from areas of application and emission vary from meters to 1000 s of kilometres depending on rates of atmospheric degradation and depositional fluxes (van Pul et al., 1998).

Most studies that have evaluated deposition have focussed on collection and analysis of rain. Generally this is relatively simple compared to dry deposition measurements that involve both 
pesticides in the gas phase and those sorbed to particulate matter and aerosols. Wania et al. (1998), have described the process of pesticide scavenging from air by rainfall. Equilibrium partitioning between vapour-phase pesticides and raindrops is typically assumed, with Henry's Law constants and temperature governing the process.

Like pesticide volatilization, the occurrence and deposition of pesticides in rain has been the focus of a very large number of published investigations spanning more than 5 decades. They have included reports of detection of legacy pesticides, like DDT, as well as numerous products in current use (Wheatley and Hardman, 1965; Dubus et al., 2000). Monitoring was conducted in remote areas, approximately $1000 \mathrm{~km}$ away from pesticide sources, at stations at intermediate distance (1 to $100 \mathrm{~km}$ ), and within areas $<1 \mathrm{~km}$ where the pesticides were applied (Dubus et al, 2000; Potter et al., 2014; Van Dijk and Guicherit, 1999).

In some studies measured deposition was related to the mass of pesticides used in contributing areas. For example, Vogel et al. (2008), reported that total pesticide wet deposition measurements made in 4 agricultural watersheds ranged from 0.06 to $1.73 \%$ of applied. The highest deposition rate was in the local-scale area where the pesticides were applied to agricultural fields. This value is comparable to surface runoff rates that are commonly observed, $\approx 1 \%$ of applied (Wauchope et al., 1995). Potter et al. (2014) estimated that about $0.1 \%$ of the insecticide endosulfan applied to farm fields in Southern Florida was deposited locally in rainfall. In another investigation that linked surface runoff to volatilization, Gish et al. (2011), found that the volatilization mass loss of the herbicides atrazine and metolachlor when applied 
preemergence to bare soils was 2 to $>130$ and 10 and >150 times the mass loss in runoff; however deposition was not measured.

Findings that volatilization of some active ingredients may greatly exceed runoff rates and that wet deposition of pesticides at least at the local scale may be comparable, suggests that pesticide volatilization and wet deposition may need to be considered in risk assessments of pesticide use. The human and ecological risks of pesticide volatilization and deposition were discussed in detail at an international symposium in 1998 (Guicherit et al., 1999). The symposium included recommendations for approaches that may be used to incorporate volatilization and deposition into regulatory risk assessments (Bakker et al., 1999; Gilbert, 1999). However these processes are not currently an integral part of risk assessment processes. For example, in USA pesticide release into the atmosphere is evaluated, but the focus is on drift and post-volatilization transport of fumigants (USEPA, 2016). Wet deposition is not considered.

We measured wet deposition of 14 current-use and 2 legacy pesticide active ingredients and 1 degradate within a small farm scale (123 ha) watershed in south central Georgia (USA) for 3 years. The watershed is intensively farmed with more than $50 \%$ of the land in mixed crop production (Lowrance et al, 2007). We hypothesized that frequent rainfall during growing seasons and high rates of pesticide use in the watershed would contribute to relatively high rates of pesticide wet deposition. Wet deposition measurements were used to support first-tier risk assessments and to identify the upper bounds of pesticide wet deposition in watersheds in the region. 


\section{MATERIALS AND METHODS}

Study area and sample collection location. The study was conducted within a 123-ha drainage basin near Tifton, GA (Fig. 1) that forms a headwater for a stream flowing into the Little River, a tributary of the Suwannee River. The bowl-like basin is typical of low-order streams in this landscape with dense riparian forests on stream banks and well-drained soils in uplands that are intensively cropped (Lowrance et al, 2007). In 2007-09, land cover was vegetable and row crops $(50 \%)$ and adjacent grassed areas $(6 \%)$, mixed deciduous and evergreen forest $(33 \%)$, irrigation ponds (4\%), and low intensity "urban" development, including roads $(7 \%)$. These values differed slightly from the surrounding county, where proportions of row crop/pasture and open water covers were lower (48\% and $2 \%$, respectively), and urban and forested land cover proportions were higher (11\% and $37 \%$, respectively). Cropped areas included fields located on the University of Georgia Gibbs research farm and nearby areas in intensive commercial vegetable production (Fig. 1). Vegetable crops were: cucumber (Cucumis sativus), squash (Cucurbita pepo), green peppers (Capsicum annuит), melons (Cucumis melo), tomatoes (Solanum lycopersicum), eggplant (Solanum melongena), green beans (Phaeolus vulgaris), collards (Brassica oleracea var. viridis), and cabbage (Brassica oleracea var. capitata). They were produced using plastic mulches with drip-irrigation, and in some cases (tomatoes; eggplant) were double cropped. The principal growing season for most crops was March through October. Crops on the research farm were primarily cotton (Gossypium hirsutum L.), peanut (Arachis hypogaea L.), and field corn (Zea mays). Cotton and peanut growing seasons were May to October and, for corn, March to July. With few exceptions all farm fields were left fallow during winter months (December to February). The pesticide wet deposition collector was located on the research farm (N31 $26^{\prime} 16^{\prime \prime}, \mathrm{W} 83^{\circ} 35^{\prime} 19^{\prime}$ '; elevation 99.3 masl) in an open field midway 
between the lower boundary of research plots in rotational cotton and peanut production and a riparian forest (Fig. 1). The distance between the plots and the trees was about $25 \mathrm{~m}$. A weather station was co-located approximately $50 \mathrm{~m}$ east of the sampler (Bosch et al., 2012).

Rain sample collection. Samples were collected on an event basis using a modified MIC-B ${ }^{\circledR}$ rain sampler (Meteorologic Instruments of Canada, Richmond, ONT, Canada) equipped with a covered $0.2 \mathrm{~m}^{2}$ stainless steel funnel and lid controlled by a moisture activated sensor. A filter cartridge assembly composed (sequentially) of a Teflon ${ }^{\circledR}$ column $(12 \mathrm{~cm}$ length x $14 \mathrm{~mm}$ diameter), a Teflon ${ }^{\circledR}$ filter head containing a 45-mm diameter glass fiber filter (Whatman GF/F, $0.7 \mu \mathrm{m}$ nominal pore size), and a solid phase extraction (SPE) cartridge containing $500 \mathrm{mg}$ of Oasis ${ }^{\circledR}$ HLB copolymer beads (Waters, USA) was attached to the bottom of the funnel. A peristaltic pump was connected to the cartridge outlet, which was activated when the funnel lid was opened. The pump pulled rainwater through the filter cartridge assembly at a flow rate of 20 to $50 \mathrm{~mL} \mathrm{~min}^{-1}$. The cartridge effluent was collected in a $20-\mathrm{L}$ carboy for volume measurement. Each event was defined as any rain that fell during a 24-hr period from $10 \mathrm{AM}$ to $10 \mathrm{AM}( \pm 1$ hour) the following day and yielded greater than $100 \mathrm{~mL}(0.5 \mathrm{~mm})$. If rain occurred on weekends or holidays, samples were collected on the following work day (Monday to Friday). In this case they were composites of all rainfall during the sampling interval. After cartridges and filters were removed from the sampler, the funnel was cleaned sequentially with 50\% methanol in deionized water, and deionized water and cartridges and filters were replaced. Samples were collected between January 2007 and December 2009. The mean (standard deviation) of the ratio between the computed rainfall amount with the sampler and the rain gage was $1.01(0.54)$ indicating high collection efficiency. Over the 3-year study period the rain capture rate with the sampler, when 
compared to weather station data, was 88 to $95 \%$. The range in sample volumes was 0.1 to 26.5 with the median and interquartile range (IQR), 2.1 and 0.78 to $5.5 \mathrm{~L}$ respectively. Sample processing. SPE cartridges were dried with purified nitrogen gas, then sequentially eluted with $4 \mathrm{~mL}$ methanol and $6 \mathrm{~mL}$ methylene chloride. Combined eluents were concentrated under an $\mathrm{N}_{2}$ gas stream to $\approx 1 \mathrm{~mL}$ followed by solvent exchange to toluene using a TurboVap® Concentrator (Biotage, LLC, Charlotte, NC, USA). The final extract volume, $1 \mathrm{~mL}$, was transferred to 2-mL autosampler vials and spiked with the internal standards, $25 \mathrm{ng}$ octafluoronapthalene (for negative ions) and $5 \mu \mathrm{g}$ 2-chlorolepidine (for positive ions). Vials were sealed with Teflon-lined screw caps and stored at $-20^{\circ} \mathrm{C}$. Optima ${ }^{\circledR}$ grade solvents were obtained from ThermoFisher Scientific (Waltham, MA, USA).

Sample extract analysis. Extracts were analyzed by gas chromatography-mass spectrometry using a DSQII Thermoquest-Finnigan system (ThermoFisher Scientific, San Jose, CA, USA). Data acquisition was in the selected ion monitoring (SIM) mode using methane negative chemical ionization (NCI), and positive ion electron impact (EI) ionization. The GC column was a 30 m DB5MS ${ }^{\circledR}$ (Agilent, Santa Clara, CA, USA), with inner diameter of $0.25 \mathrm{~mm}$ and film thickness of $0.25 \mu \mathrm{m}$. Helium carrier gas flow was fixed at $2 \mathrm{~mL} \mathrm{~min}^{-1}$. Injections were in the splittless mode at $220^{\circ} \mathrm{C}$, with head pressure surged to $250 \mathrm{kPa}$ for $1 \mathrm{~min}$ after injection. Column oven temperature at injection, $80^{\circ} \mathrm{C}$, was held for 1 minute, then increased to $260^{\circ} \mathrm{C}$ at $20^{\circ} \mathrm{C} \mathrm{min}$ ${ }^{1}$ and held for 2 minutes. For NCI, methane flow was $1.5 \mathrm{~mL} \mathrm{~min}^{-1}$ and source temperature $200^{\circ} \mathrm{C}$. EI for positive ions was at $70 \mathrm{eV}$. Before analysis of each sample set, the mass spectrometer was autotuned to meet the manufacturer's PFTBA ion abundance and ratio criteria in NCI or EI modes. Target compounds, their use classification, mode of ionization, ions used for quantitation and confirmation, reporting limits (RL) in sample extracts, \% recovery by SPE 
from deionized water, estimated use in the watershed where the sampler was located, and Henry's Law constants are shown in Table 1. RLs were set as the lowest concentration standard used for calibration. Calibration and continuing calibration standards, which inserted after 20 injections in each sample set, were used to establish data for peak confirmations. Criteria included: retention time within \pm 1 standard deviation of the analytical standards; detection of all target ions; and the relative response ratio between the quantitation ion (base peak) and the next most abundant ion, within \pm the mean of the relative percent deviation (RPD) of values determined for all standards analyzed with each sample set. Analytical standards were purchased from ChemService (West Chester, PA, USA).

Quality control. Equipment blanks were evaluated monthly by processing one liter of distilleddeionized water through the rain collectors. Chlorothalonil was detected in one blank at $10 \mathrm{ng} \mathrm{L}^{-1}$ and metolachlor in another at $120 \mathrm{ng} \mathrm{L}^{-1}$. Potential impact on computed deposition rates and mean and median concentrations were $<1 \%$ when the RL for these compounds was set equal to the highest level detected in the blanks. None of the other target analytes were detected in any of the blanks. Analyte percent recovery from 0.1 ug L-1 spikes in 1-L and 8-L deionized water aliquots 57 to $130 \%$ (Table 1). The potential for analyte breakthrough during SPE of samples $>8 \mathrm{~L}$ was assessed using equations described by Lövkvist and Jonsson (1987) with partition coefficients (k) on Oasis ${ }^{\circledR}$ HLB estimated using a 5-parameter solvation model and published parameter estimates (Dias and Poole, 2002; Endo et al., 2015). Estimated volumes at 1\% breakthrough was greater than the peak sample volume, $26.5 \mathrm{~L}$, for all compounds except atrazine and malathion. The computed volumes for these compounds were $7.2 \mathrm{~L}$ and $11 \mathrm{~L}$ respectively. Comparison to the upper bound of the IQR of sample volumes, $5.5 \mathrm{~L}$, indicated potential for breakthrough in less than $25 \%$ of samples. 
Land cover and pesticide use estimates. Vegetative cover in each of the numbered fields in Fig. 1 was recorded quarterly and used to develop cropping records. Landscape features, including forest, farm fields, irrigation ponds and roads were digitized from high resolution 2009 aerial photography of Tift County (USDA-FSA, 2009), using a geographic information system (GIS) running ArcGIS for Desktop (v. 10.3, Advanced; 2014). Field areas were computed to give the area for each crop type biannually to capture the double cropping patterns when practiced. Total yearly area was then summed for each crop type harvested. The cropped area in the basin was $68 \mathrm{ha}$, but due to double-cropping, the harvested area was 73 ha, 96 ha, and 74 ha during the respective years 2007 to 2009 . Watershed-scale annual pesticide use estimates were computed by multiplying harvested area times the USDA National Agriculture Statistics Service pesticide use crop survey data (USDA-NASS, 2016). When available, survey data for Georgia (USA) in crop year 2010 were used, otherwise the 2010 data for all programs states were used. To our knowledge all pesticides were applied using tractor mounted sprayers at ground level. No data were available describing the actual use and timing of pesticide applications.

Data analysis. Deposition was calculated by multiplying the measured sample volume times the corresponding concentration of each analyte. As noted, during the study, rainfall capture when compared to the weather station was 88 to $95 \%$. Deposition values were divided by the area of the sampler funnel opening $\left(0.2 \mathrm{~m}^{2}\right)$ to determine deposition per unit area $\left(\mu \mathrm{g} \mathrm{m}^{-2}\right)$. To test the sensitivity of deposition calculations to how $<$ RL values were handled, two approaches were taken: 1) zero was inserted for all values $<\mathrm{RL}$ and 2) the RL was inserted for all values $<\mathrm{RL}$. All statistical tests and "Box-and whisker" plots of concentration data were made with SigmaPlot ${ }^{\mathrm{TM}}$ 13.0 (SysStat Software Inc., San Jose, CA, USA). When preparing plots, the RL was inserted when values were $<$ RL. Tests for normality (Shapiro-Wilk) indicated that both concentration and 
deposition data were not normally distributed. Thus, pair-wise comparisons of medians were made using the Mann-Whitney rank sum "t-test". Significant differences were identified when $p$ was $<0.05$. Estimates of concentration means and medians based on Kaplan-Meier (KM) survival analyses were computed using the KM-stats v. 1.4 excel spreadsheet (Helsel, 2013). The KM method likely provides more accurate estimates when sample sets have relatively high percentages $(>15 \%)$ of not detected values, and when there are multiple detection limits (Helsel, 2005). This was the case with our data due to differences in sample volumes of rainfall events. Based on the recommendation of Antweiler and Taylor (1998), KM estimates were not computed for data sets with $>70 \%$ non-detects.

\section{RESULTS AND DISCUSSION}

Detection and concentration in rain samples. Two fungicides, 8 herbicides, 5 insecticides, and tribufos, an active ingredient used for cotton defoliation (tribufos), were targeted in analyses (Table 1). Tests related to the insecticide, endosulfan, included its $\alpha$ - and $\beta$-isomers, and their primary soil degradate, endosulfan sulfate. Estimated use of the targeted compounds within the watershed indicated that, on a mass basis, they represented $61 \%$ of conventional pesticides used during the 3-yr study period with chlorothalonil, accounting for $44 \%$ of the total. There was no reported local use of the two "legacy compounds" lindane and its isomer, $\alpha$-BHC. They were included as analytes as indicators of long-range transport (Shen et al., 2005). In addition, no local agricultural use of two of the herbicides, oxadiazon and dacthal was indicated. Oxadiazon was included because of its use on turf, while dacthal is registered for use on numerous vegetable crops and has been detected in rainfall in other studies (Kurt-Karakus et al., 2011). 
Among the compounds which were routinely detected estimated use within the watershed tracked detection frequency and concentration in nearly all cases (Table 1; Table 2).

Chlorothalonil had the highest use and highest detection frequency, means, medians, and peak concentrations, $97 \%$ and 435- 453, 139-153, and $4700 \mathrm{ng} \mathrm{L}^{-1}$ respectively. High rates of chlorothalonil detection (approaching $100 \%$ ) have been in observed in numerous other studies that were linked to the pesticide's local and/or regional use (Brun et al., 2008; Goel et al., 2005; Hüskes and Levson, 1997; Kuang et al., 2003; Kurt-Karakus et al., 2011). The highest reported peak, 1100 to $2010 \mathrm{ng} \mathrm{L}^{-1}$, and mean concentrations, 86 to $160 \mathrm{ng} \mathrm{L}^{-1}$, (Goel et al., 2003; Kuang et al., 2005) were 2 to 3 -fold lower than our measured values. We also expect that detection of chlorothalonil in rain samples (and other pesticides) was linked to post application volatilization and re-deposition. This is primarily due to the location of the sampler. It was south-southeast of the farm fields that had the highest estimated use rate. The extensive forested buffer between these fields and the sampler which would likely have captured application related drift (Fig 1.).

As indicated in Table 2 means and medians were computed for all observations using KM statistics (Helsel, 2005) and using the detected values only. There was good agreement between the two approaches for chlorothalonil and total endosulfans since detection rates were high, $>94 \%$. For the other compounds, detection rates were $<58 \%$, thus the KM approach likely provided the least biased estimates (Helsel, 2005). "Box and Whisker" concentration plots of all with $>30 \%$ detected values are shown in Figure 3. Pair-wise comparisons showed that chlorothalonil's median was significantly greater than all other compounds, and that total endosulfan, metolachlor and pendimethalin medians were significantly greater than the medians of chlorpyrifos, ethalfluralin and trifluralin. 
Chlorothalonil's high use rate, frequent detection and the relatively high chlorothalonil concentration in rain samples can be attributed to its repeated application to plant canopies over several months. For example, on peanut $7-8$ applications at $\approx 1 \mathrm{~kg} \mathrm{ha}^{-1}$ are commonly made during growing seasons (Potter et al, 2001). The product is used similarly on many vegetable crops. The impact of plant canopy application is that limited soil contact reduces the potential for chlorothalonil binding to soil organic matter and/or degradation. Binding to soil organic matter reduces pesticide volatilization losses and, in part, explains why volatilization from plant canopies may be 2 to 3 times higher than from soil under the same meteorological conditions (Sarigiannis et al, 2013). In soil, chlorothalonil $t_{1 / 2}<2 d$ have been reported (Potter et al., 2001), thus degradation may be very rapid. In contrast, once in the atmosphere, chlorothalonil is relatively stable when compared to other pesticides due to its resistance to reaction with hydroxyl radicals (Matthies et al, 2009).

Detection rates of total endosulfan were also high $>94 \%$, however, peak, mean, and median concentrations were about 8-fold less than chlorothalonil (Table 2). Here, total endosulfan concentration was computed as the sum of the $\alpha$-isomer, $\beta$-isomer, and/or the degradate, endosulfan sulfate. Detection rates for all three compounds, 49 to $87 \%$, and means and medians of $\alpha$-isomer and endosulfan sulfate concentration, were 2 to 3 times less than the $\beta$-isomer. Estimated endosulfan use was about 10 times less than chlorothalonil (Table 1), but, like chlorothalonil, numerous applications may be made during growing seasons. In addition, high volatility and atmospheric stability has been indicated. Kennedy et al. (2001) reported that endosulfan post-application volatilization from cotton may exceed $70 \%$ of applied, and there are 
frequent reports of endosulfan detection in arctic environments, 1000s of kilometers from where the compound is used (Matthies et al, 2009).

Endosulfan's $\beta$-isomer was detected more frequently than the $\alpha$-isomer and peak mean and median concentrations were greater even though the $\alpha$-isomer concentration in technical endosulfan is more than 2-fold greater (Weber et al., 2010). This behavior has been reported in other studies and was related to differences in Henry's law constants (Table 1), with the lower $\beta$ isomer value contributing to a higher rainfall washout rate (Weber et al, 2010). The ratio of mean and median concentrations of the $\alpha$ - and $\beta$-isomer concentrations, $\approx 0.20$, was also comparable to previously published results (Potter et al., 2014). Overall, the magnitude of concentration measurements were intermediate with results about 3 times higher than investigations conducted in agricultural watershed located on Maryland's (USA) Eastern Shore (Goel et al., 2003; Kuang et al., 2005), but 3 times less than values reported for wet deposition in an area of southern Florida where endosulfan use rates are very high (Potter et al, 2014).

In the case of endosulfan sulfate, our results were unusual since the overall detection rate, $87 \%$, was higher than both isomers (Table 2). Typically, endosulfan sulfate detection rates are much lower than the parent compound in wet deposition studies (Weber et al., 2010; Potter et al, 2014). A possible explanation of our findings is that treated vegetable fields (fields 5 and 6; Fig. 1) were within $0.5 \mathrm{~km}$ of the deposition collector. Crops produced in these fields included tomato and eggplant, thus endosulfan use was expected, and accumulation of endosulfan sulfate in soil was likely. This created potential for windblown soil containing endosulfan sulfate to reach the sampler. Endosulfan sulfate is formed in soil and binds strongly to soil organic matter (Weber et 
al., 2010). Because samples were glass fiber filtered and extracted by SPE in field, no direct observations of the presence or absence of particulate matter in samples were made.

Detection frequency of the herbicides metolachlor, trifluralin, ethalfluralin, atrazine and pendimethalin were intermediate, ranging from 31 to $58 \%$ (Table 2). As with endosulfan and chlorothalonil, these compounds are commonly reported in wet deposition studies where regional and local sources were linked (Dubus et al, 2000; Vogel et al., 2008). Their relatively low detection rate may in part be explained by their pattern of application. Typically, a single application is made to bare soil at or near planting. This results in a narrow application window, and its potential to bind to soil organic matter reduces volatilization potential (Sarigiannis et al., 2013). A narrow application window may also help to explain the relatively high measured peak concentrations of atrazine, metolachlor, and pendimethalin (Table 2). Values were in the range reported for agricultural watersheds in the mid-Western USA where use rates of these herbicides are very high (Vogel et al., 2008).

As was the case with these herbicides, the pattern of use of the defoliant, tribufos, appeared to explain low detection rates, $23 \%$, but relatively high peak concentration, $1200 \mathrm{ng} \mathrm{L}^{-1}$. Single applications to cotton crops just prior to harvest are made, thus the application window is narrow. In addition, in October and November, when cotton is harvested in the region, rainfall rates are low (Potter et al., 2015).

Trifluralin and ethalfluralin estimated use rates in our watershed were lower than other herbicides that had intermediate rates of detection. A factor that likely impacted ethalfluralin 
results was use of granular formulations and or post-application soil incorporation. Soil incorporation within $24 \mathrm{~h}$ of application to peanut to reduce ethalfluralin volatilization losses is recommended (Prostko, 2009).

Chlorpyrifos and tebuconazole, which are also used on peanut, had moderate use but low detection rates, 35 and $11 \%$, respectively. Like chlorothalonil, tebuconazole is commonly applied numerous times during growing seasons, contributing to broad application windows and the potential for detection in rainfall. However, the compound is classed as "non-volatile" due to its low Henry's law constant (Table 1; Footprint, 2016), thus volatilization rates are low. In addition, tebuconazole is systemic and rapidly taken up by treated plants (Potter et al, 2015). This further reduces post-application volatilization potential and chances of detection in rain samples. In contrast, chlorpyrifos’ Henry's Law constant indicates moderate volatility (Table 2). To reduce losses when applied to peanut, granular formulations are used with soil incorporation at planting (Gomez, 2009). This presumably reduces potential for volatilization loss and detection in rain. It should also be noted that chlorpyrifos is labeled for use on some of the vegetable crops, with applications made to crop canopies. This was also a likely source for detections in rain samples.

Four of the targeted compounds malathion, metribuzin, oxadiazon, and $\alpha$-BHC were detected sporadically, in $<5 \%$ of samples, and lindane was not detected. This was anticipated since no $\alpha$ BHC, lindane, oxadiazon, and or dacthal use was indicated in pesticide use estimates, while estimated use of malathion and metribuzin was only a small fraction of the total of pesticides applied $(<1 \%)$. As noted the legacy compounds, $\alpha-\mathrm{BHC}$ and lindane, were included to assess 
potential for long-range atmospheric transport to the watershed. There was only one detection, thus impacts appeared to be limited.

In pesticide wet deposition studies, detection of two or more pesticides in samples is typical (Dubus et al., 2000). In our study, the median number of detections was 6, and results showed that summing concentrations by compound class may substantially increase concentrations. For example, the herbicide mean volume weighted concentration in May was more $9000 \mathrm{ng} \mathrm{L}^{-1}$ (Fig. 3). This mean was more than 2 times higher than the peak concentrations of any of the individual compounds that contributed across all samples.

Generally, there were strong seasonal patterns of pesticide use, with highest monthly volume weighted concentration means observed during periods when products were used (Fig. 3). Again, this is common in pesticide wet deposition studies (Dubus et al., 2000). The highest herbicide levels were observed in spring (May-June) when row crops like peanut, cotton and corn were planted. Peak defoliant (tribufos) concentration was in October and November, when defoliants are applied and cotton is harvested. In the case of the fungicides and insecticides, means were relatively constant throughout the summer months reflecting multiple applications during growing seasons (May to September). Finally, comparison of the \%RSD for monthly volumeweighted concentration measurements, $140 \%$, to the value for the 3 - study years, 50\%, indicated that monthly variation was much greater than annual variation.

Wet deposition. Wet deposition tracked measured concentration and use. Annual and total deposition rates for compounds with the highest deposition rates were, in descending order: 
chlorothalonil $>$ pendimethalin $>$ metolachlor $>$ tribufos $>$ total endosulfans $>$ chlorpyrifos $>$ atrazine> tebuconazole (Table 3). Overall, the manner in which measurements that were $<\mathrm{RL}$ was handled in computations had small impact, with relative percent deviation between 1 and 20 $\%$. For brevity, further discussion of deposition focuses on values computed when the RL was inserted for $<\mathrm{RL}$ measurements, with no further discussion of compounds with very low detection rates $(<5 \%)$ and deposition rates.

Chlorothalonil mean annual deposition, $210 \mu \mathrm{g} \mathrm{m}{ }^{-2}$, was significantly greater than most compounds (Table 3). The exceptions were for the two herbicides, pendimethalin and metolachlor. Their annual deposition means were >2-fold less than chlorothalonil, but means were not significantly less. This was due to relatively high measured deposition in 2009 when pendimethalin deposition was 5- to10-fold and the metolachlor 3- to 4-fold greater than in 200708. High 2009 deposition was linked to three storm events near the time when row crops are typically planted in the watershed and herbicides like metolachlor and pendimethalin are applied. Deposition during these events accounted for $>25 \%$ of the 3 -yr deposition of these compounds.

Vogel et al. (2008), described similar herbicide wet deposition behavior. Thus, it appears that storm event timing with respect to application is an important factor in the magnitude of pesticide wet deposition. Another example was the deposition behavior of the defoliant tribufos in our study. The 2009 deposition was 3-fold higher than in 2007-08 due to high rates of deposition associated with a few storms in October and November that accounted for $>50 \%$ of the 3-yr deposition total. Seasonal trends in deposition also emphasized that deposition was impacted by application-storm event timing (Fig. 4). Herbicides which were typically applied in 
the spring, had the highest mean monthly deposition rates in May and June. Consistent with application time, the highest deposition rate of the defoliant was in October and November. Fungicide and insecticide deposition was greatest in July and August when they were used most intensively.

Published pesticide wet deposition studies can serve as a basis of comparison to our data. For example, Goel et al. (2005) monitored deposition of numerous pesticide active ingredients in agricultural watershed eastern Maryland (USA). Chlorothalonil had the highest mean (standard deviation) annual deposition rate, $54(23) \mu \mathrm{g} \mathrm{m}^{-2} \mathrm{yr}^{-1}$ of all targeted analytes. This was about 4 times less than the amount measured in the current study (Table 3). Likely explanations of differences include the intensity of chlorothalonil use and differences in meteorological conditions and management practices. This also likely explained higher deposition for metolachlor, pendimethalin, and endosulfan in our study. However only total endosulfan results were significantly greater when compared to Goel et al (2005). We are aware of only one higher deposition rate when compared to the Table 3 total endosulfan value. Mean annual deposition was $73 \mu \mathrm{g} \mathrm{m}^{-2} \mathrm{yr}^{-1}$ in an agricultural area in southern Florida where there was very high endosulfan use (Potter et al, 2014). In the case of atrazine, there was little difference between deposition measured in our study site and values reported by Goel et al. (2005). However, Vogel et al. (2008), reported atrazine deposition up to 20 times higher in a watershed in the Midwest, USA, where it was used during corn production.

Vogel et al. (2008), also estimated total pesticide deposition as a percent of the amounts applied within four watersheds where crop production was the dominant land use, with the assumption 
that rainfall was evenly distributed across the watersheds. When pesticide use data at the local scale was evaluated, annual deposition ranged from 0.06 to $1.73 \%$ of applied. We took a similar approach and found that deposition was $0.26 \%$ of the estimated amounts of the targeted compounds applied within the watershed (Table 4). The range for individual analytes was 0.05 to $12 \%$. The highest value, which was for atrazine, appears to be an outlier. There are several possible explanations, including failure to account for atrazine use within the watershed, as well transport from use areas outside the watershed area. It must be emphasized that the watershed boundaries do not necessarily define the contributing airshed that may impact pesticide wet deposition. The relatively high value for the tribufos, $4.2 \%$ of applied, also appears anomalous, and the same rationale applies.

Potential impact of wind direction on deposition was evaluated by relating daily average wind direction to deposition. Results showed that about $60 \%$ of the insecticide, fungicide, and herbicide deposition was observed when the wind was blowing in southerly direction from the vegetable fields North and West of the sampler location. This indicated that pesticides used on these fields were a primary source of these pesticides detected in wet deposition samples (Fig. 1; Fig. 5).

In the case of defoliant, tribufos, this assessment showed that $>60 \%$ of the deposition occurred when winds were blowing from the east and southeast (Fig. 5). The fields where cotton was grown in the watershed and where the defoliant may been applied were north and south of the sampler position (Fig. 1). Thus, it appears that a primary source may have been outside the watershed. This was indicated by the relatively high estimated tribufos deposition when expressed as a percent of applied in the watershed. 
The finding that endosulfan and chlorothalonil had similar deposition rates, 0.21 and $0.15 \%$ of applied (Table 4), respectively, was likely related to their synchronous use on vegetable crops within the watershed. In addition, the similarity in deposition rates, when expressed as a percent of the amount applied, suggests that their physical-chemical behavior was similar. This includes emission from treated fields during and after application, as well as washout from the atmosphere. The latter is indicated by similarity in the Henry's Law constants of chlorothalonil and $\beta$-endosulfan, 0.025 versus 0.040 , respectively (Table 1 ). The $\beta$-isomer was the predominant form of endosulfan in wet deposition samples.

The total endosulfan deposition rate, $0.21 \%$ of applied, was close to the value estimated by Potter et al. (2014), $0.1 \%$ of applied, for a vegetable crop production area in Southern Florida. This suggests that values in this range may be typical of humid subtropical areas such as southern Florida and Georgia where endosulfan was used.

Implications for risk and environmental fate assessment. A common practice in ecological risk assessment is to compare measured and/or predicted environmental concentrations to established ecotoxicological endpoints. This approach was recommended for pesticide wet deposition assessments (Guicherit et al., 1999). To that end, we compared the concentrations of the target pesticides to the most sensitive ecological risk endpoints available. Measured concentrations of five of the targets exceeded their respective endpoints. The $\%$ of samples exceeding endpoints was $77,21,15,5$, and $1 \%$ for endosulfan, chlorothalonil, chlorpyrifos, malathion, and atrazine, respectively (Table 5). In nearly all cases the samples with 
concentrations that exceeded endpoints were collected during growing seasons when the pesticides were applied.

The high frequency of detection of endosulfan in rainfall, above the chronic toxicity threshold, was linked to the very low level at which it can have toxic impact (Table 5). Chlorpyrifos and malathion also have low chronic toxicity endpoints, thus, many samples exceeded toxic thresholds even through their frequency of detection and mean concentrations were much lower than endosulfan (Table 4). The chronic toxicity endpoint for chlorothalonil is about 60 times greater than that of endosulfan. As result, the relative number of samples exceeding endpoints was less, even though the mean concentration in rain samples was 9 times greater.

These data suggest the likelihood of ecological risks due to wet deposition of pesticides within the watershed, and indicate a need for further assessment taking into account dilution and attenuation following deposition, as well as the combined toxic impacts of all residues detected in samples. The median number of residues detected in samples was 6 . However, given recent changes in regulatory status, this may not be necessary for endosulfan. Technical endosulfan was listed as persistent organic pollutant (POP) by the Stockholm Convention in 2011 and uses are being phased out worldwide (UNEP-POP, 2016).

In comparison, relatively low ecological risk though wet deposition for the herbicides measured in rain samples was indicated. Atrazine was the only target detected above its most sensitive ecotoxicological endpoint and this was only in one sample. Further consideration of the toxicity of herbicides however may be needed. As noted, the median number of pesticide detections in 
samples was 6, and as indicated in Fig. 4, summing the individual contributions of all detected residues may result in high monthly volume-weighted mean concentrations.

Finally, data showed that wet deposition of metolachlor should be included in environmental fate assessments. Metolachlor wet deposition, $\approx 1 \%$ of applied (table 5), was more than 5 -fold greater than the amounts measured in surface runoff from peanut fields in the watershed (field 18 in Fig. 1) (Potter et al., 2014). This may be explained by metolachlor's relatively high volatility. Gish et al. (2011) found that the volatilization mass loss of metolachlor, when applied preemergence to bare soils, was 10 and to more than 150 times the mass loss in surface runoff. In contrast to metolachlor, tebuconazole runoff from the same peanut fields averaged $3.2 \%$ of applied, whereas wet deposition was only $0.26 \%$ (Table 4). The much lower wet deposition rate compared to surface runoff can be attributed tebuconazole's low volatility (Table 1; Footprint, 2016). Data suggest that a ranking scheme based on relative potential for volatilization losses after application may be useful in determining whether wet deposition risks from local application should be included in fate and risk assessments. This was previously proposed by Van Den Berg et al. (1999). It also is clear that pesticide deposition measurements within defined airsheds rather watersheds would prove beneficial in determining potential impacts of pesticide volatilization and deposition.

\section{DISCLOSURE STATEMENT}

All authors hereby certify that they have no actual or potential conflict of interest including any financial, personal or other relationships with other people or organizations within three (3) years 
of beginning the work submitted that could inappropriately influence (bias) their work. The work is a U.S. Government product.

\section{ACKNOWLEDGEMENTS}

Numerous field and technical staff, students, and volunteers contributed to success of the project.

We especially thank Margie Whittle, Sally Belflower, and Rex Blanchett and our USDA-ARS colleague, Cathleen Hapeman, for use of the rain sampler.

\section{LITERATURE CITED}

Abbott, DC, Harrison, RB, Tatton, O'G, Thomson, J. Organochlorine Pesticides in the Atmospheric Environment. Nature 1965, 208, 1317-1318.

Alletto, L, Coquet, Y, Benoit, P, Heddadj, D, Barriuso, E. Tillage management effects on pesticide fate in soils. A review. Agron. Sustain. Dev. 2009, 30, 367-400.

Antweiler, RC, Taylor, HE. Evaluation of statistical treatments of left-censored environmental data using coincident uncensored datasets: I. summary statistics. Environ. Sci. Technol. 2008, 42, 3732-3738.

ArcGIS for Desktop. 10.3, Advanced. December 2014. Environmental Systems Research Institute, Inc., Redlands, CA.

Bakker, DJ, Gilbert, AJ, Gottschild, D, Kuchnicki, T, Laane, RWPM, Linders, JBHJ, Van De Meent, D, Montforts, MHMM, Pino, J, Pol, JW, Van Straalen, M.. Implementing Atmospheric Fate in Regulatory Risk Assessment of Pesticides: (How) Can it be Done? Water Air Soil Pollut. 199, 115, 257-266. 
Barbash, J.E. The geochemistry of pesticides. p. 541-577. In H.D.Holland and K.K. Turekian (ed.) Treatise on geochemistry. Pergamon, Oxford, UK. 2003.

Bedos, C, Cellier, P, Calvet, R, Barriuso, E, Gabrielle, B. Mass transfer of pesticides into the atmosphere by volatilization from soils and plants: overview. Agronomie 2002, 22, 21-33.

Bedos C, Rousseau-Djabri MF, Loubet B, Durand B, Flura D, Briand O, Barriuso E. Fungicide volatilization measurements: inverse modeling, role of vapor pressure, and state of foliar residue. Environ. Sci. Technol. 2010, 44, 2522-8.

Bosch, D.D., Truman, C.C., Potter, T.L., West, L.T., Strickland, T.C., Hubbard, R.K. Tillage and Slope Position Impact on Field-scale Hydrologic Processes in the South Atlantic Coastal Plain. Agric. Wat. Manage. 2012, 111, 40-52.

Brun, GL, MacDonald RM, Verge, J., Aube, J. Long-term atmospheric deposition of current-use and banned pesticides in Atlantic Canada; 1980-2000. Chemosphere 2008, 71, 314-327.

Dias, NC, Poole, CF. Mechanistic study of the sorption properties of OASIS ${ }^{\circledR}$ HLB and its use in solid-phase extraction. Chromatographia 2002, 56, 269-275.

Dubus, IG, Hollis, JM, Brown, CD. Pesticides in rainfall in Europe. Environ. Poll. 2000, 110, $331-344$.

Endo, S., Watanabe, N., Ulrich, N., Bronner, G., Goss, K.-U., UFZ-LSER database v 2.1 [Internet], Leipzig, Germany, Helmholtz Centre for Environmental Research-UFZ. 2015 [http://www.ufz.de/index.php?en=31698\&contentonly=1\&m=0\&lserd_data[mvc]=Public/star $\underline{\mathrm{t}}$; last accessed October 31, 2016] 
Footprint. The FOOTPRINT Pesticide Properties DataBase. Database collated by the University of Hertfordshire as part of the EU-funded FOOTPRINT project (FP6-SSP-022704). [http://sitem.herts.ac.uk/aeru/ppdb/en/Reports/336.htm; last accessed October 31, 2016].

Gilbert, A.J. Regulatory risk assessment of pesticide residues in air. Water Air Soil Pollut. 1999, 115, 183-194.

Gish, TJ, Prueger, JH, Daughtry, CST, Kustas, WP, McKee, LG, Russ, AL, Hatfield, JL. Comparison of Field-scale Herbicide Runoff and Volatilization Losses: An Eight-Year Field Investigation. J. Environ. Qual. 2011, 40, 1432-1442.

Goel A, McConnell LL, Torrents AA. Wet deposition of current use pesticides at a rural location on the Delmarva Peninsula: impact of rainfall patterns and agricultural activity. J Agric. Food Chem. 2005, 53, 7915-24.

Gomez, LE. Use and Benefits of Chlorpyrifos in U.S. Agriculture. Dow AgroSciences LLC, Indianapolis, IN, USA. 2009.

[www.chlorpyrifos.com/pdf/ChlorpyrifosUseBenefits_18May2009.pdf; last accessed October $31,2016]$.

Guicherit, R, Bakker, DJ, De Voogt, P, Van Den Berg, F. Van Dijk, HFG, Van Pul, WAJ. Environmental Risk Assessment for Pesticides in the Atmosphere; the Results of an International Workshop. Water Air Soil Pollut. 1999, 115, 5-19.

Helsel, DR. Nondetects and Data Analysis: Statistics for Censored Environmental Data. John Wiley \& Sons, New York. 2005.

Helsel, DR. KMStats v 1.4: Excel worksheet to compute the Kaplan-Meier estimate of mean and UCL95. 2013. [http://www.practicalstats.com/nada/downloads.html; last accessed October $31,2016]$. 
Hüskes, R, Levsen, K. Pesticides in rain. Chemosphere 1997, 35, 3013-3024.

Kennedy IR, Sánchez-Bayo F, Kimber SW, Hugo L, Ahmad N. Off-site movement of endosulfan from irrigated cotton in New South Wales. J Environ Qual. 2001, 30, 683-96.

Kuang Z, McConnell LL, Torrents A, Meritt D, Tobash S. Atmospheric deposition of pesticides to an agricultural watershed of the Chesapeake Bay. J Environ Qual. 2003, 32, 1611-22.

Kurt-Karakus, PB, Teixeira, C, Small, J, Muir, D, Bidelman, TF. Current-use pesticides in inland lake waters, precipitation, and air from Ontario, Canada. Environ. Toxicol. Chem., 2011, 30, $1539-1548$.

Lowrance, R., Sheridan, JM, Williams, RG, Bosch, DD, Sullivan, DG, Blanchett, DR, Hargett, LM, Clegg, CM. Water quality and hydrology in farm-scale coastal plain watersheds: Effects of agriculture, impoundments, and riparian zones. J. Soil Wat. Conserv., 2007, 62, 6576.

Lövkvist, P., Jonsson, JA. Capacity of sampling and preconcentration columns with a low number of theoretical plates. Anal. Chem. 1987, 59, 818-821.

Majewski, MS, Capel, PD. Pesticides in the atmosphere: Distribution, trends, and governing factors. Ann Arbor Press, Chelsea, MI. 1995.

Matthies, M, Klasmeier, J, Beyer, A, Ehling, C. Assessing persistence and long-range transport potential of current-use pesticides. Environ. Sci. Technol., 2009, 43, 9223-9229.

Potter, T.L., Bosch, D.D., Strickland, T.C. Comparative assessment of herbicide and fungicide runoff risk: a case study for peanut production in the Southern Atlantic Coastal Plain (USA). Sci. Total Environ. 2014, 490, 1-10. 
Potter, TL, Hapeman, CJ, McConnell, LL, Harman-Fetcho, JA; Schmidt, WF, Rice, CP, Schaffer, B. Endosulfan wet deposition in southern Florida. Sci. Total Environ. 2014, 468-69, $505-513$.

Potter, TL, Wauchope, RD, Culbreath, AK Accumulation and decay of chlorothalonil and selected metabolites in surface soil following foliar application to peanuts. Environ. Sci. Tech. $2001,35,2634-2639$.

Prostko, E. 2009. 2009 Peanut Weed Control Recommendations. University of Georgia, Tifton, GA.

Sarigiannis DA, Kontoroupis P, Solomou ES, Nikolaki S, Karabelas AJ. Inventory of pesticide emissions into the air in Europe. Atmos. Environ. 2013, 75, 6-14.

Shen, L, Wania, F, Lei, YD, Teixeira, C, Muir, DCG, Bidleman, TF Atmospheric distribution and long-range transport behavior of organochlorine pesticides in North America. Environ. Sci. Tech. 2005, 39, 409-420

Spencer, WF, Farmer, WJ, Cliath, MM, Pesticide volatilization. Res. Reviews. 1973, 49, 1-47.

UNEP-POP. SC-5/3: listing of technical endosulfan and its related isomers. United Nations Environment Program Stockholm Convention on Persistent Organic Pollutants; 2011 [http://chm.pops.int/TheConvention/ThePOPs/ListingofPOPs; last accessed October 31, 2016].

USDA-FSA, Aerial Photography Field Office (2009) NAIP 2009 Imagery. U.S. Department of Agriculture, Farm Service Agency, Aerial Photography Field Office, Salt Lake City, UT USDA-NASS. USDA National Agricultural Statistics Service. Data and Statistics. 2016. [https://www.nass.usda.gov/Surveys/Guide_to_NASS_Surveys/Chemical_Use/index.php; last accessed October 31, 2016] 
USEPA. Aquatic Life Benchmarks for Pesticide Registration. US Environmental Protection Agency Office of Pesticide Programs, Washington, DC, USA. 2016a.

[https://www.epa.gov/pesticide-science-and-assessing-pesticide-risks/aquatic-lifebenchmarks-pesticide-registration\#use.; last accessed October 31, 2016].

USEPA. Atmospheric Models. U.S. Environmental Protection Agency Office of Pesticide Programs, Washington, DC. 2016b [available on-line at https://www.epa.gov/pesticidescience-and-assessing-pesticide-risks/models-pesticide-risk-assessment\#agdisp; last accessed October 31, 2016].

USEPA. Refined Ecological Risk Assessment for Atrazine. U.S. Environmental Protection Agency Office of Pesticide Programs, Washington, DC. 2016c [https://www.regulations.gov/document?D=EPA-HQ-OPP-2013-0266-0315; last accessed October 31, 2016].

Van Den Berg, F., Kubiak, R, Benjey, WG, Majewski, MS, Yates, SR, Reeves, GL, Smelt, JH, Van der Linden, AMA. Emission of Pesticides into the Air. pp 195-218. In Van Dijk, Van Pul, WAJ, De Voogt, P. Fate of Pesticides in the Atmosphere: Implications for Environmental Risk Assessment. Proceedings of a workshop organized by The Health Council of the Netherlands, held in Driebergen, The Netherlands, April 22-24, 1998. ISBN: 978-90-481$5329-9$.

Van Dijk, HFG., Guicherit, R. 1999. Atmospheric dispersion of current-use pesticides: A review of the evidence from monitoring studies. Water Air Soil Pollut. 1999, 115, 21-70.

Van Pul, WAJ, Bidleman, TF, Brorström-Lundén, E., Builtjes, PJH, Dutchak, S., Duyzer, JH, Gryning, S-E, Jones, KC, Van Dijk, HFG, Van Jaarsveld, JA. Atmospheric Transport and 
Deposition of Pesticides: An Assessment of Current Knowledge. Water Air Soil Pollut. 1999, $115,245-256$.

Vogel, JR, Majewski, MS, Capel, PD. Pesticides in Rain in Four Agricultural Watersheds in the United States. J. Environ. Qual. 2008, 37, 1101-1115.

Wania F, Axelman J, Broman D. A review of processes involved in the exchange of persistent organic pollutants across air-sea interfaces. Environ Pollut. 1998, 102, 3-23.

Wauchope, RD, Graney, RL, Cryer, S., Eadsworth, C., Klein, AW, Racke, KD. Pesticide runoff: methods and interpretation of field studies. Pure Appl. Chem. 1995, 67, 2089-2108.

Weber J, Halsall CJ, Muir D, Teixeira C, Small J, Solomon K, et al. Endosulfan, a global pesticide: a review of its fate in the environment and occurrence in the Arctic. Sci Total Environ. 2010, 408, 2966-84.

Wheatley, GA, Hardman, JA. Indications of the presence of organochlorine insecticides in rainwater in Central England. Nature 1965,207, 486-487.

Woodrow, JE, Seiber, JN, Baker, LW. Correlation techniques for estimating pesticide volatilization flux and downwind concentrations. Environ. Sci. Technol. 1997, 31, 523-529. 
Table 1. Target compounds, compound use class, mode of ionization, SIM ions, reporting limit $(\mathrm{RL})$, range in mean \% recovery of analytes spiked into deionized water, estimated annual use within the watershed where study was conducted, and Henry's Law constants.

\begin{tabular}{|c|c|c|c|c|c|c|}
\hline & & & RL & & & $\mathrm{H}^{\S}$ \\
\hline compound & class & SIM ions & $\left(\mu \mathrm{g} \mathrm{mL} L^{-1}\right)$ & $\%$ rec $^{\#}$ & use $(\mathrm{kg})^{\delta}$ & $\left(\mathrm{Pa} \mathrm{m}^{3} \mathrm{~mol}^{-1}\right)$ \\
\hline chlorothalonil & fungicide & 266,264 & 0.001 & $96-120$ & 510 & $2.5^{*} 10^{-2}$ \\
\hline$\alpha$-endosulfan & insecticide & 242,406 & 0.001 & $91-92$ & $38^{\pi}$ & $0.72 ! !$ \\
\hline$\beta$-endosulfan & insecticide & 242,406 & 0.001 & $93-110$ & $16^{\mathbb{\pi}}$ & $0.04 ! !$ \\
\hline endosulfan sulfate & degradate & 384,386 & 0.001 & $94-110$ & $\mathrm{NR}^{¥}$ & $\approx 0.015^{! !}$ \\
\hline metolachlor & herbicide & $162^{\dagger}, 238$ & 0.01 & $110-120$ & 30 & 0.48 \\
\hline pendimethalin & herbicide & 281,282 & 0.01 & $87-99$ & 28 & $2.7 * 10^{-3}$ \\
\hline ethalfluralin & herbicide & $\mathbf{3 3 3}, 303$ & 0.001 & $62-82$ & 26 & 18 \\
\hline tebuconazole & fungicide & 125,250 & 0.01 & $120-130$ & 17 & $1.0 * 10^{-5}$ \\
\hline chlorpyrifos & insecticide & 214,313 & 0.001 & $83-95$ & 13 & $2.4 * 10^{-3}$ \\
\hline trifluralin & herbicide & 335,305 & 0.001 & $57-82$ & 11 & 10 \\
\hline malathion & insecticide & 172,157 & 0.01 & $99-120$ & 11 & $1.0 * 10^{-3}$ \\
\hline tribufos & defoliant & 257,259 & 0.001 & $86-100$ & 3.2 & $2.9 * 10^{-2}$ \\
\hline metribuzin & herbicide & 198,199 & 0.01 & $91-103$ & 1.5 & $2.0 * 10^{-5}$ \\
\hline atrazine & herbicide & $200^{\dagger}, 215$ & 0.01 & $90-107$ & 0.4 & $1.5 * 10^{-4}$ \\
\hline$\alpha-\mathrm{BHC}$ & insecticide & 255,257 & 0.005 & $83-91$ & NR & - \\
\hline lindane & insecticide & 255,257 & 0.005 & $84-97$ & NR & $1.5^{*} 10^{-6}$ \\
\hline dacthal & herbicide & 332,330 & 0.001 & $91-99$ & NR & - \\
\hline
\end{tabular}


oxadiazon herbicide $\quad 344,267 \quad 0.01 \quad 92-100) \quad$ NR $\quad 3.8 * 10^{-2}$

$\ddagger$ quantitation (bold; italics) and confirmation ions; ${ }^{\dagger} \mathrm{EI}=$ electron impact ionization otherwise negative chemical ionization; ${ }^{\#}$ range of mean $\%$ recovery by solid phase extraction of $0.1 \mu g \mathrm{~L}^{-1}$ spike in $1 \mathrm{~L}$ and $8 \mathrm{~L}$ aliquots of deionized water. ${ }^{\delta}$ estimated use within the watershed during 2007-09; ${ }^{\text {II }}$ estimated total technical endosulfan $100 \mathrm{~kg}$ was assumed to a 30/70 mix of the $\alpha$ - and $\beta$-isomers. ${ }^{*}$ endosulfan sulfate is a degradate of endosulfan. ${ }^{\S}$ Henry’s Law Constant at $25^{\circ} \mathrm{C}$ (Footprint, 2016); "' Values from Weber et al. (2010). 
Table 2. Summary statistics for target analytes in rain samples during 2007 to 2009.

\begin{tabular}{|c|c|c|c|c|c|c|c|}
\hline & \multirow[b]{2}{*}{$\%$ detected } & \multirow[b]{2}{*}{$\min$} & \multicolumn{2}{|c|}{ detected values $^{\dagger}$} & \multirow[b]{2}{*}{ median } & \multicolumn{2}{|c|}{$\mathrm{KM}^{\S}$} \\
\hline & & & $\max$ & $\begin{array}{c}\text { mean } \\
(\text { stdev })^{\ddagger}\end{array}$ & & $\begin{array}{l}\text { mean } \\
\text { (stdev) }\end{array}$ & median \\
\hline chlorothalonil & 97 & 0.3 & 4700 & $450(710)$ & 150 & $440(710)$ & 140 \\
\hline total endosulfans & 94 & 0.2 & 450 & $54(77)$ & 24 & $51(75)$ & 22 \\
\hline$\alpha$-endosulfan & 49 & 0.4 & 59 & 11(16) & 3.3 & $6(12)$ & 6 \\
\hline$\beta$-endosulfan & 71 & 0.2 & 359 & $46(63)$ & 21 & $33(7)$ & 33 \\
\hline endosulfan sulfate & 87 & 0.7 & 97 & $15(17)$ & 10 & $14(16)$ & 8 \\
\hline pendimethalin & 58 & 1.5 & 1700 & $170(340)$ & 43 & $100(280)$ & 10 \\
\hline atrazine & 50 & 0.9 & 1030 & $68(130)$ & 33 & $35(98)$ & 4 \\
\hline ethalfluralin & 46 & 0.1 & 267 & $15(41)$ & 1.8 & $7(29)$ & 1 \\
\hline trifluralin & 43 & 0.1 & 33 & $4(6)$ & 1.4 & $2(5)$ & 0 \\
\hline chlorpyrifos & 35 & 4.3 & 870 & $80(130)$ & 39 & $28(85)$ & 0 \\
\hline metolachlor & 31 & 15 & 3800 & $510(780)$ & 213 & $160(490)$ & 0 \\
\hline tribufos & 23 & 8.3 & 1200 & $190(290)$ & 68 & - & - \\
\hline dacthal & 15 & 0.1 & 3.6 & $0.6(1)$ & 0.3 & - & - \\
\hline tebuconazole & 11 & 50 & 2000 & $240(440)$ & 106 & - & - \\
\hline malathion & 5 & 1.2 & 690 & $110(240)$ & 27 & - & - \\
\hline
\end{tabular}




\begin{tabular}{cccccccc} 
metribuzin & 3 & 1.3 & 12 & $5.3(4)$ & 4.3 & - & - \\
oxadiazon & 2 & 5.2 & 42 & $18(21)$ & 6.2 & - & - \\
a-BHC & 1 & 1.1 & 1.1 & 1.1 & 1.1 & - & - \\
lindane & 0 & ND & ND & ND & ND & - & \\
\hline
\end{tabular}

${ }^{\dagger}$ measured concentration greater than the reporting limit $(\mathrm{RL}) ;{ }^{\dagger}$ stdev $=$ standard deviation; ${ }^{\S}$ mean \pm standard deviation and median based on Kaplan-Meier survival statistics when $\%$ detections were $>30 \%$ and RLs were inserted when values were <RL (Helsel, 2013). 
Table 3. Deposition summary for target analytes in rain samples during 2007 to 2009 .

\begin{tabular}{|c|c|c|c|c|c|}
\hline & TOTAL & 2007 & 2008 & 2009 & 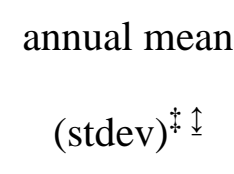 \\
\hline \multirow[t]{2}{*}{ rain $(\mathrm{mm})$} & 3268 & 816 & 1275 & 1178 & $1090(240)$ \\
\hline & \multicolumn{5}{|c|}{----- $\mu \mathrm{g} \mathrm{m}^{-2}$} \\
\hline chlorothalonil & 640 & 210 & 260 & 170 & $210(45)^{\mathrm{a}}$ \\
\hline pendimethalin & $270-280$ & $19-20$ & $41-42$ & $210-220$ & $92(110)$ \\
\hline metolachlor & 240 & $54-56$ & $44-46$ & 140 & $80(52)$ \\
\hline tribufos & 110 & 21 & 18 & 69 & $36(29)^{\mathrm{a}}$ \\
\hline total endosulfans & 91 & 31 & 32 & 28 & $30(2)^{\mathrm{ab}}$ \\
\hline$\alpha$-endosulfan & $14-15$ & $6.5-6.7$ & $5.2-5.3$ & $2.6-2.7$ & $5(2)^{\mathrm{abc}}$ \\
\hline$\beta$-endosulfan & 56 & $16-17$ & 20 & 20 & $19(2)^{\mathrm{abcd}}$ \\
\hline endosulfan sulfate & 21 & 8.6 & 6.7 & $5.7-5.9$ & $7(1)^{\text {abcde }}$ \\
\hline chlorpyrifos & 43 & $1.2-1.5$ & 26 & 15 & $14(12)^{\mathrm{ab}}$ \\
\hline atrazine & $36-40$ & $13-15$ & $12-13$ & $11-13$ & $13(1)^{\text {abcef }}$ \\
\hline tebuconazole & $32-39$ & $15-17$ & $17-19$ & $<0.1-2.3$ & $12(9)^{\mathrm{ab}}$ \\
\hline ethalfluralin & 16 & $6.9-7.1$ & $3.8-3.9$ & $5.1-5.3$ & $5(2)^{\mathrm{abdf}}$ \\
\hline trifluralin & $4.3-4.8$ & $0.1-0.3$ & $1.1-1.3$ & 3.1 & $2(1)^{\mathrm{abdf}}$ \\
\hline malathion & $3.7-11$ & $0.5-3.0$ & $3.2-5.9$ & $<0.1-2.3$ & - \\
\hline
\end{tabular}




$\begin{array}{cccccr}\text { dacthal } & 0.4-1.1 & 0.2-0.5 & 0.1-0.4 & 0.1-0.3 & - \\ \text { metribuzin } & 0.5-8.1 & 0.3-2.8 & 0.1-3 & <0.1-2.3 & - \\ \text { oxadiazon } & 0.5-8.3 & 0.5-3.1 & <0.1-2.9 & <0.1-2.3 & - \\ \text { a-BHC } & <0.1-3.9 & <0.1-1.4 & <0.1-1.5 & <0.1-1.2 & - \\ \text { lindane } & <0.1-3.9 & <0.1-1.4 & <0.1-1.5 & <0.1-1.2\end{array}$

$\$$ when a range is shown the lower values was computed by inserting zero for values $<\mathrm{RL}$ and with the higher value the RL was inserted when concentrations was <RL; when a single value is shown the values using the two RL insertion techniques were equal. ${ }^{\star}$ means and standard deviation (stdev) were computed when the RL was inserted for concentrations values $<\mathrm{RL}$ in

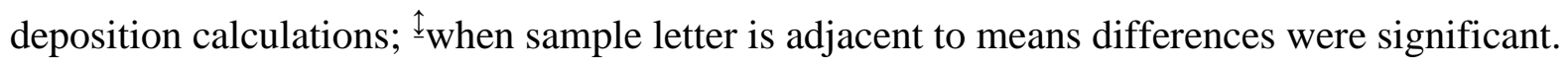


Table 4. Pesticide estimated use within the watershed and deposition during the 3 years of the study.

\begin{tabular}{|c|c|c|c|}
\hline & $\begin{array}{l}\text { estimated use }^{\dagger} \\
\text { kg }\end{array}$ & $\begin{array}{l}\text { measured } \\
\text { deposition } \\
\text { kg }\end{array}$ & $\begin{array}{l}\text { deposition } \\
\% \text { of applied }\end{array}$ \\
\hline chlorothalonil & 520 & 0.79 & 0.15 \\
\hline endosulfan & 52 & 0.11 & 0.21 \\
\hline metolachlor & 30 & 0.30 & 1.0 \\
\hline pendimethalin & 27 & 0.35 & 1.2 \\
\hline ethalfluralin & 26 & 0.02 & 0.08 \\
\hline trifluralin & 14 & 0.01 & 0.05 \\
\hline tebuconazole & 17 & 0.04 & 0.26 \\
\hline tribufos & 3.2 & 0.14 & 4.2 \\
\hline chlorpyrifos & 14 & 0.05 & 0.39 \\
\hline metribuzin & 1.5 & 0.005 & 0.33 \\
\hline malathion & 8.9 & 0.01 & 0.08 \\
\hline atrazine & 0.49 & 0.05 & 12 \\
\hline total pesticides & 720 & 1.9 & 0.26 \\
\hline
\end{tabular}


Table 5. Most sensitive ecological risk endpoints for aquatic organisms and $\%$ of rain samples with concentration exceeding endpoints. ${ }^{+\dagger}$

\begin{tabular}{|c|c|c|c|}
\hline compound & $n g L^{-1}$ & endpoint type & $\%$ exceeding \\
\hline chlorothalonil & 600 & aquatic invertebrates chronic & 21 \\
\hline endosulfan ${ }^{\complement}$ & 10 & aquatic invertebrates chronic & 77 \\
\hline metolachlor & 8000 & non vascular plants acute & 0.0 \\
\hline pendimethalin & 5200 & non vascular plants acute & 0.0 \\
\hline ethalfluralin & 400 & fish chronic & 0.0 \\
\hline tebuconazole & 12000 & fish chronic & 0.0 \\
\hline chlorpyrifos & 40 & aquatic invertebrates chronic & 17 \\
\hline trifluralin & 1140 & fish chronic & 0.0 \\
\hline malathion & 35 & aquatic invertebrates chronic & 5.0 \\
\hline tribufos & 1560 & aquatic invertebrates chronic & 0.0 \\
\hline metribuzin & 8700 & non vascular plants acute & 0.0 \\
\hline atrazine & $<1000$ & non vascular plants acute & $<1.0$ \\
\hline a-BHC & $\mathrm{NR}^{\mathrm{II}}$ & $\mathrm{NR}^{\mathrm{I}}$ & 0.0 \\
\hline lindane & 500 & aquatic invertebrates chronic & 0.0 \\
\hline dacthal & $>11 * 10^{6}$ & non vascular plants acute & 0.0 \\
\hline oxadiazon & 5200 & non vascular plants acute & 0.0 \\
\hline
\end{tabular}


${ }^{\ddagger}$ Aquatic Life Benchmarks for Pesticide Registration (USEPA, 2016b); ${ }^{\dagger}$ Refined Ecological Risk Assessment for Atrazine (USEPA, 2016b) $;{ }^{\uparrow}$ toxicity of $\alpha$ - and $\beta$ - endosulfan isomers and endosulfan sulfate were assumed equal (Weber et al, 2010); ${ }^{\mathbb{T}} \mathrm{NR}=$ not reported. 


\section{Figure headings.}

Figure 1. Sampler location and land use within the watershed. Numbered fields refer to identifiers used in quarterly vegetative cover surveys.

Figure 2. Box and whisker plot of measured concentrations with reporting limits (RL) inserted when values were $<$ RL. $1=$ chlorothalonil; $2=$ metolachlor; $3=$ pendimethalin; $4=$ total endosulfans ( $\alpha$-endosulfan $+\beta$-endosulfan + endosulfan sulfate $) ; 5=$ atrazine $; 5=$ chlorpyrifos; 7 $=$ ethalfluralin; $8=$ trifluralin. Where same letters are shown on plot, medians were not significantly different.

Figure 3. Mean (standard deviation) monthly volume weighted concentrations with data aggregated by pesticide use type.

Figure 4. Mean (standard deviation) monthly wet deposition with data aggregated by pesticide use type.

Figure 5. Relative percentage of total 3-yr pesticide deposition aggregated by pesticide use type as function of the compass bearing of the daily average wind direction measured at 5-m above the ground surface. $\mathrm{N}=$ north, $\mathrm{NE}=$ northeast, $\mathrm{NW}=$ northwest; $\mathrm{E}=$ =ast, $\mathrm{W}=$ west; $\mathrm{S}=$ south, $\mathrm{SE}=$ southeast, $\mathrm{SW}=$ southwest. 
Figure 1.

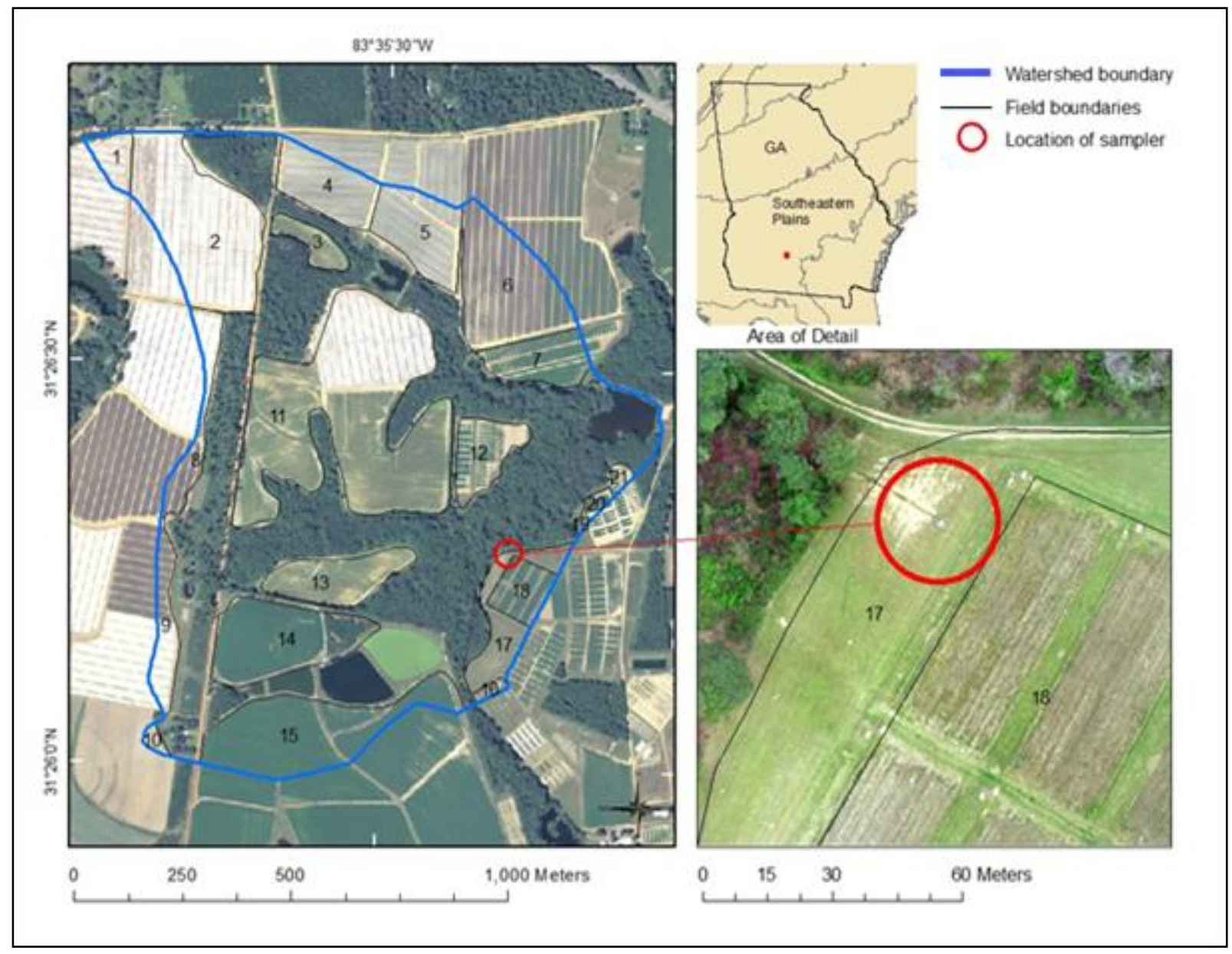


Figure 2.

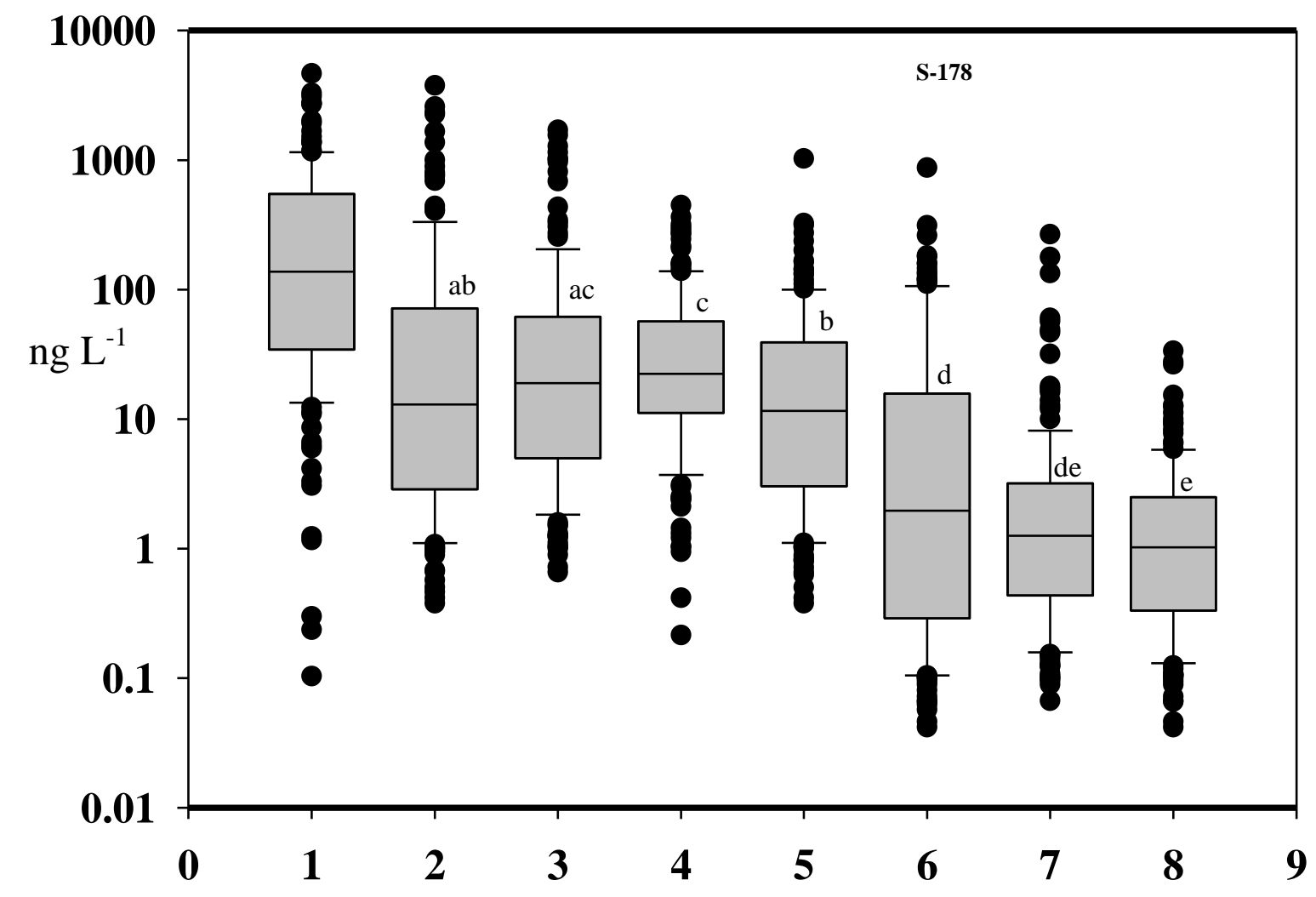


Figure 3.

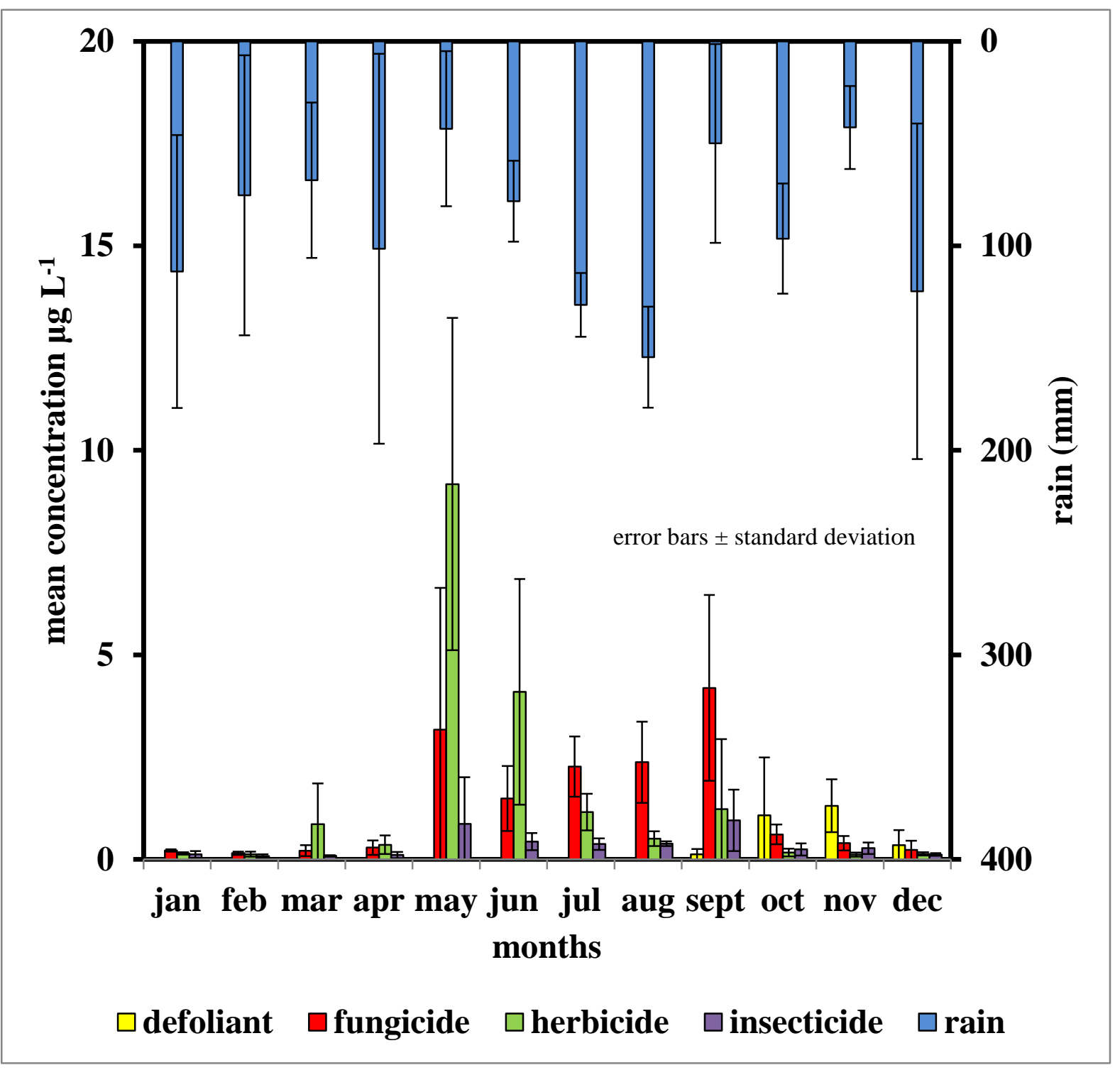


Figure 4.

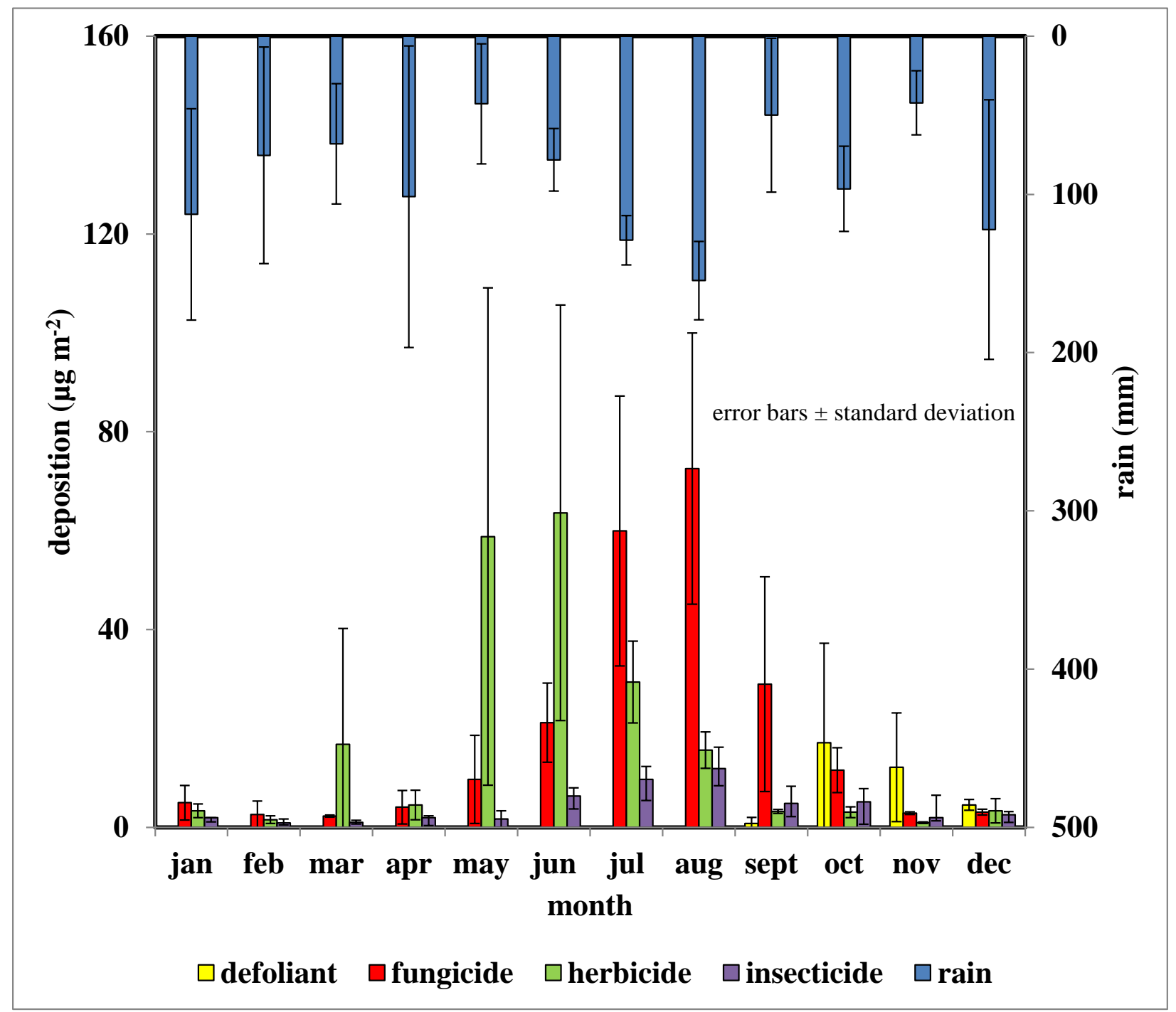


Figure 5.

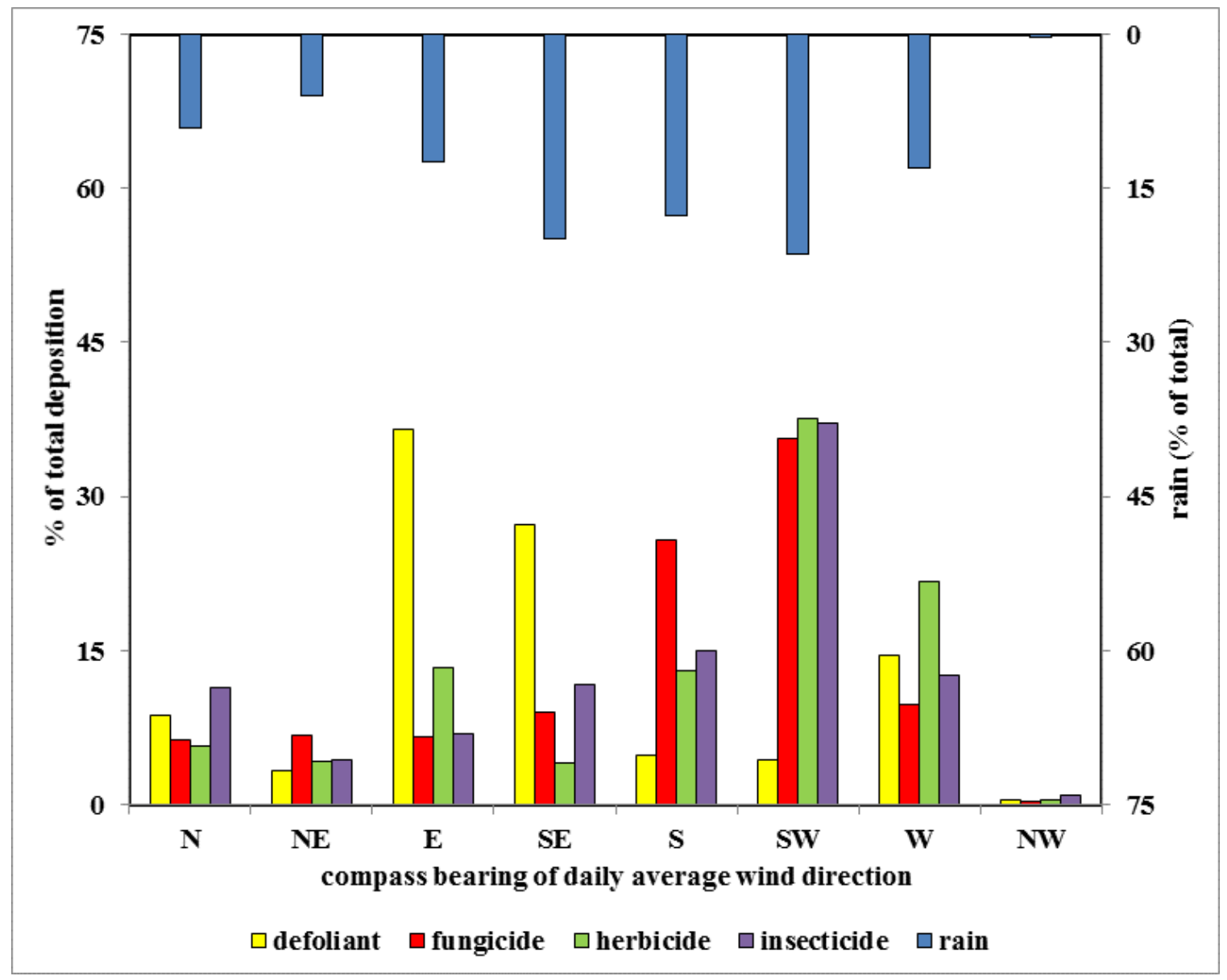




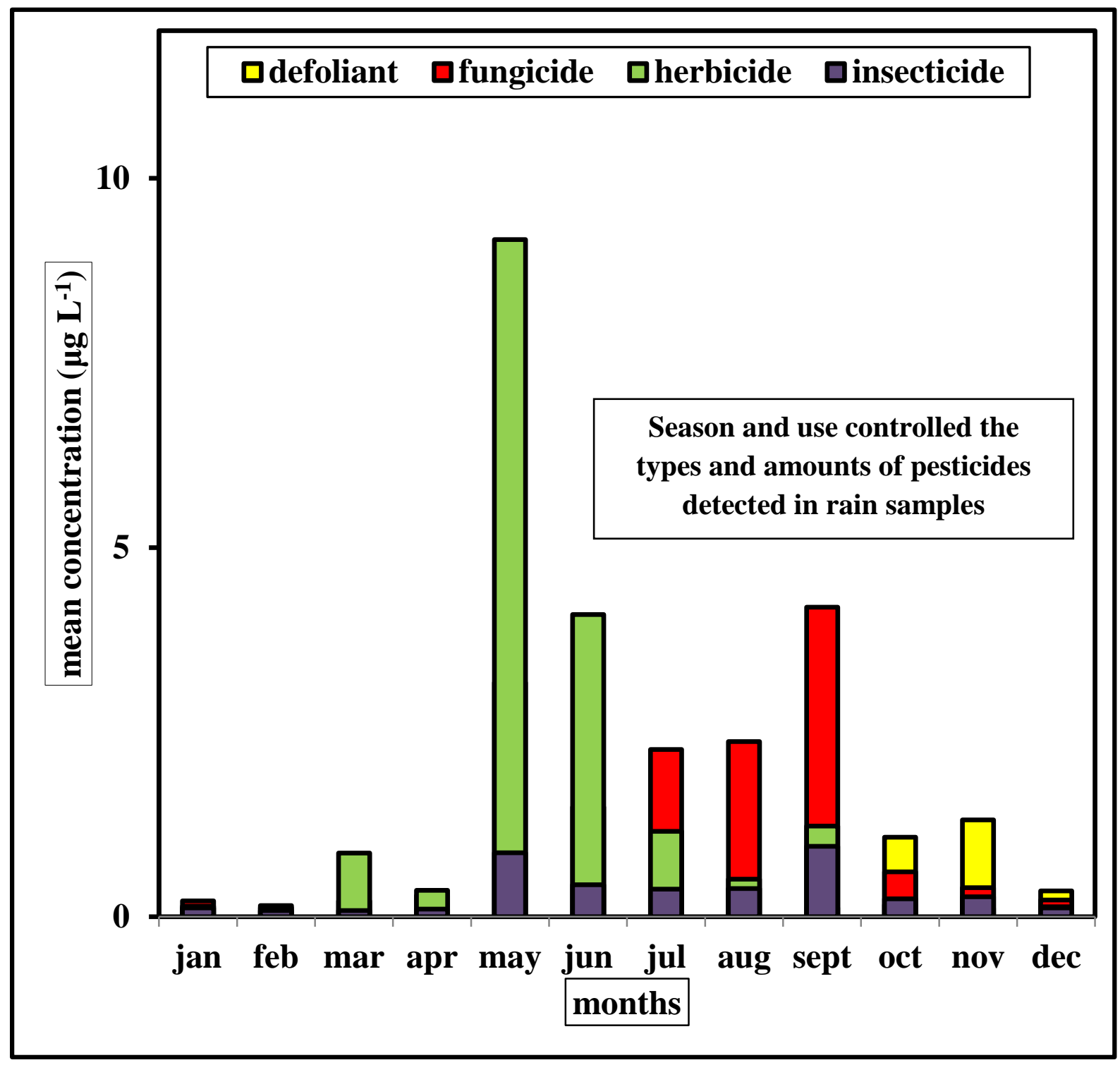

